\title{
PROJEVY ZDROJOVÝCH OBLASTÍ SEDIMENTŮ V ZRNITOSTNÍM SLOŽENÍ KORYTOVÝCH AKUMULACÍ VODNÍCH TOKŮ V RELIÉFU BUDOVANÉM FLYŠOVÝMI HORNINAMI
}

\author{
Stream-bed sediments as indicators of sediment sources in flysh areas \\ Václav Škarpich, Tomáš Galia \\ Katedra fyzické geografie a geoekologie PřF OU, Chittussiho 10, 71000 Ostrava-Slezská Ostrava; e-mail: vaclav.skarpich@osu.cz
}

(25-23 Rožnov pod Radhoštěm, 25-41 Vsetín)

Key words: Hostýn-Vsetín Mts., Javorníky Mts., headwater streams, fluvial sediments, colluvial sediments

\begin{abstract}
The character of bed sediments reflects fluvial processes and the dynamics of material transport in fluvial (dis)continuum systems. The approach in this study was based on the measurement of the five largest boulders located within a channel, and on the observation of changes in their size in the longitudinal profile of headwater streams Kobylská and Pulčinský potok. All three axes (dimensions) of the five largest boulders were measured at $10 \pm 1 \mathrm{~m}$ intervals of the longitudinal profile. The resulting trends in a particle-size index reflect the character of sediment delivery into the channel segment. The largest boulders were observed in channel sections with a strong interaction of slope processes. But local lithological conditions affect changes of the mean value of the particle-size index of the largest boulders. The role of slope processes can be accentuated by the presence of uniform sandstone lithology of the studied bed particles. In the lithology built by claystone layers the role of slope processes has problematic identification. The main reason is erodible character of claystone layers which affects sediment supply of finer particles from adjacent slopes into the channel segment.
\end{abstract}

\section{Úvod}

Vysokogradientové části toku jsou důležitou součástí ř́íního kontinua, resp. (dis)kontinua (Fryirs et al. 2007). Tyto úseky jsou považovány za tzv. zdrojové oblasti sedimentů v povodí, kdy materiál ze svahů vstupuje gravitačním pohybem do koryta a je dále transportován fluviálními procesy do nižších partií povodí (Mongomery Buffington 1997; Owczarek 2008). V současné literatuře se těmito zdrojovými oblastmi povodí zabývají některé studie, ve kterých se objevuje metodika identifikace těchto zdrojnic v návaznosti na odezvě v morfologických parametrech koryta (např. sklon a šírka koryta; Theler et al. 2010; Recking et al. 2012) nebo zrnitostním složení dnových sedimentů akumulovaných v korytě (např. hrubnutí sedimentu $\mathrm{v}$ důsledku vyšší dotace materiálu z přilehlých svahů atp.; Golden - Springer 2006; Galia - Škarpich 2013). Obecně je výsledný charakter korytových sedimentů odrazem poměrů donášky sedimentů a transportní kapacity toku. V reliéfu tvořeném flyšovými horninami je však identifikace vlivu zdrojů sedimentů na korytotvorné procesy značně obtížná. Dủležitou roli sehrává litologie hornin budujících danou oblast, tedy mocnost vrstev, petrografické složení a zrnitost hornin. Problematický může být třeba pohled na odezvu zrnitostního složení povrchové vrstvy sedimentů dna koryta v území s hrubě lavicovitými flyšovými horninami a jemně rytmickými flyšovými horninami. U reliéfu, který je budovaný pískovcovými horninami, se mohou zdrojové oblasti sedimentů projevit $\mathrm{v}$ akumulačních tvarech v korytě vodního toku lokálním hrubnutím sedimentu. Důvodem je především vliv velikosti sedimentů vstupujících do koryta, které není vodní tok schopen transportovat. Naopak u reliéfu, který je budován jemně rytmickými sedimentárními, např. jílovcovými horninami, jsou tyto projevy smazány právě vstupem většího množství jemnějších zrnitostních frakcí z okolních svahů do koryta a vliv konkrétních zdrojů se v toku nemusí projevit (Škarpich et al. 2010; Galia - Škarpich 2013). Projev fluviálních procesů je tak ve velikosti klastů akumulovaných v korytě velmi těžko identifikovatelný právě z důvodu vstupu těchto jemnějších frakcí sedimentů, které je vodní tok schopen transportovat (Škarpich et al. 2010).

Cílem této studie je popsat odezvu zrnitostních parametrů sedimentů akumulovaných v korytě v závislosti na dodávce sedimentů do koryta u povodí budovaných hrubě lavicovými flyšovými horninami. Předpoklad dodávky sedimentů je charakterizován v určitých úsecích koryt výskytem větších klastů, které není vodní tok schopen transportovat během povodňových průtoků. Uplatňuje se zde především vliv gravitačně podmíněného koluviálního transportu z okolních svahů a tento materiál je poté po určitý čas uložen v korytě.

\section{Zájmové území}

Zájmovým územím jsou povodí dvou vysokogradientových toků: Kobylské v Hostýnsko-vsetínské hornatině a Pulčínského potoka v Javornících (viz obr. 1). Povodí Kobylské je $\mathrm{v}$ převážné části budováno vsetínskými vrstvami zlínského souvrství s prrevládajícím petrografickým složením flyšových hornin s vápnitými jílovci a mocnějšími vrstvami glaukonitických pískovců (Pesl 1991; Krejčí 1991). V nejhornějších partiích povodí jsou potom zastoupeny bělovežské vrstvy račanské jednotky s drobně rytmicky se střídajícími rudohnědými a zelenošedými jílovci. Studovaný úsek koryta je charakterizován sklonem od 0,05 do $0,15 \mathrm{~m} / \mathrm{m}$, některé úseky dosahují sklonu až $0,20 \mathrm{~m} / \mathrm{m}$. V korytě toku se hojně vyskytují vyšší skalní stupně (obr. 2a). Místy se vyskytují rozsáhlé břehové nátrže $s$ rozsahem $v$ podélném směru průběhu koryta od 5 do $15 \mathrm{~m}$ a výškou místy i $5 \mathrm{~m}$ (viz obr. 2b). V horní části povodí má koryto stržovitý charakter a je zde před- 


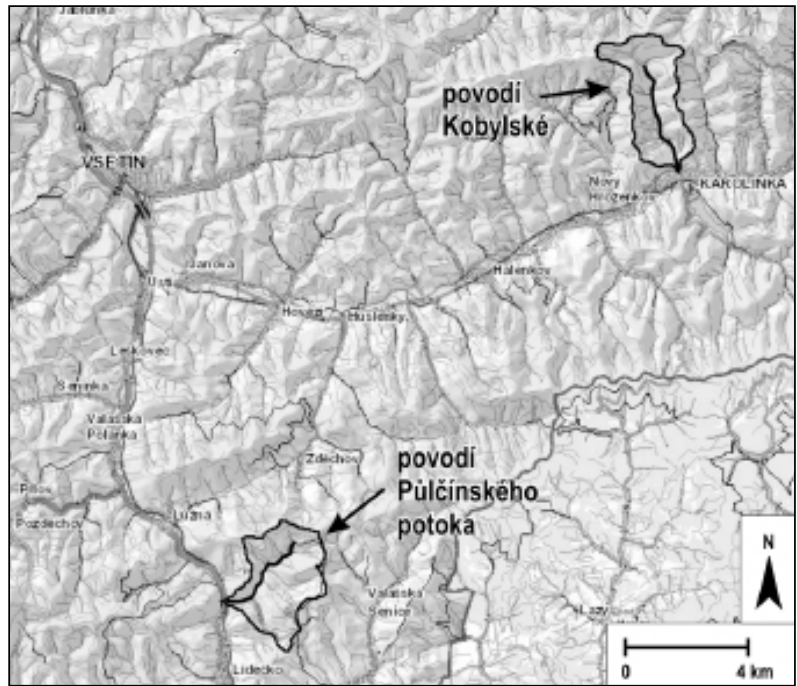

Obr. 1: Lokalizace studovaných vodních toků a jejich povodí v Hostýnsko-vsetínské hornatině a Javornících (zdroj podkladových dat: http://geoportal.cenia.cz/).

Fig. 1: Localisation of the studied streams and their basins in the Hostýn-Vsetín Mts. and Javorníky Mts. (data source: http:// geoportal.cenia.cz/). poklad vysoké dodávky sedimentů do koryta koluviálním transportem z okolních svahů. Dolní část studovaného úseku je charakterizována spíše neckovitým údolím v př́ičném profilu, ve kterém koryto tvoří zákruty o poloměru cca $20 \mathrm{~m}$. Délka studovaného úseku byla $810 \mathrm{~m}$. Celková plocha povodí vodního toku Kobylská je 6,74 km².

Povodí Pulčínského potoka je budováno luhačovickými vrstvami zlínského souvrství (račanská jednotka) s vrstvami hrubozrnných arkózových a drobových pískovců až drobnozrnných slepenců. Místy jsou zde zastoupeny újezdské vrstvy zlínského souvrství (račanská jednotka) s hrubozrnnými vrstvami arkózových a drobových pískovců (Krejčí 1991). Studovaný úsek koryta vodního toku Pulčínský potok se vyznačuje sklonem od 0,05 m/m do $0,10 \mathrm{~m} / \mathrm{m}$ (viz obr. 3a, b). Břehové nátrže $\mathrm{v}$ tomto úseku se vyskytují výjimečně a mají rozměry max. do $5 \mathrm{~m}$ $\mathrm{v}$ podélném průběhu vodního toku $s$ výškou max. $1 \mathrm{~m}$. Tyto nátrže jsou však v současnosti zpevněny kořenovými systémy vegetace. V korytě se také ve velké míře objevují zbytky dřeva, které mají významnější vliv na hydraulické poměry (viz obr. 3a, b). Příčný profil údolí má charakter neckovitého údolí (viz obr. 3a), ve kterém vodní tok charak-

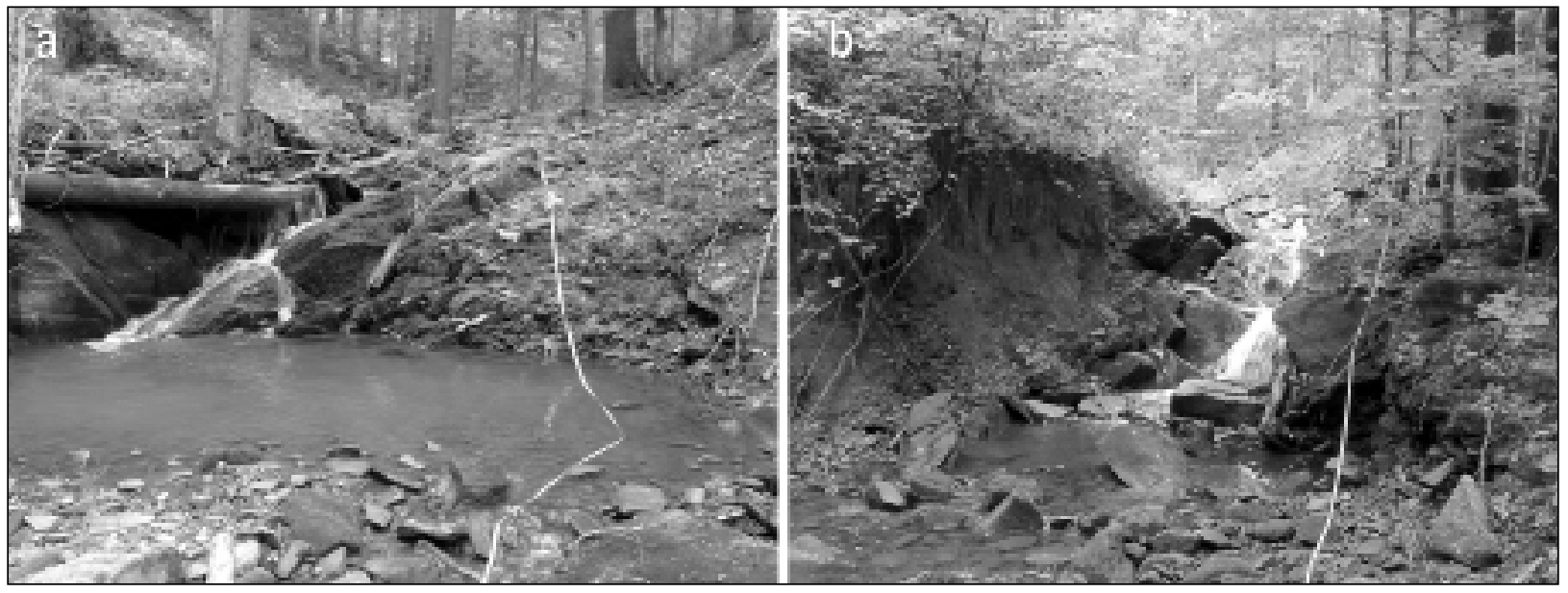

Obr. 2: a - Skalní stupně v korytě ve studovaném úseku Kobylská; b - břehová nátrž v údolním dně toku Kobylská.

Fig. 2: a - Bedrock steps in the studied reach of the Kobylská stream; b - bank failure in the valley bottom of the Kobylská stream.
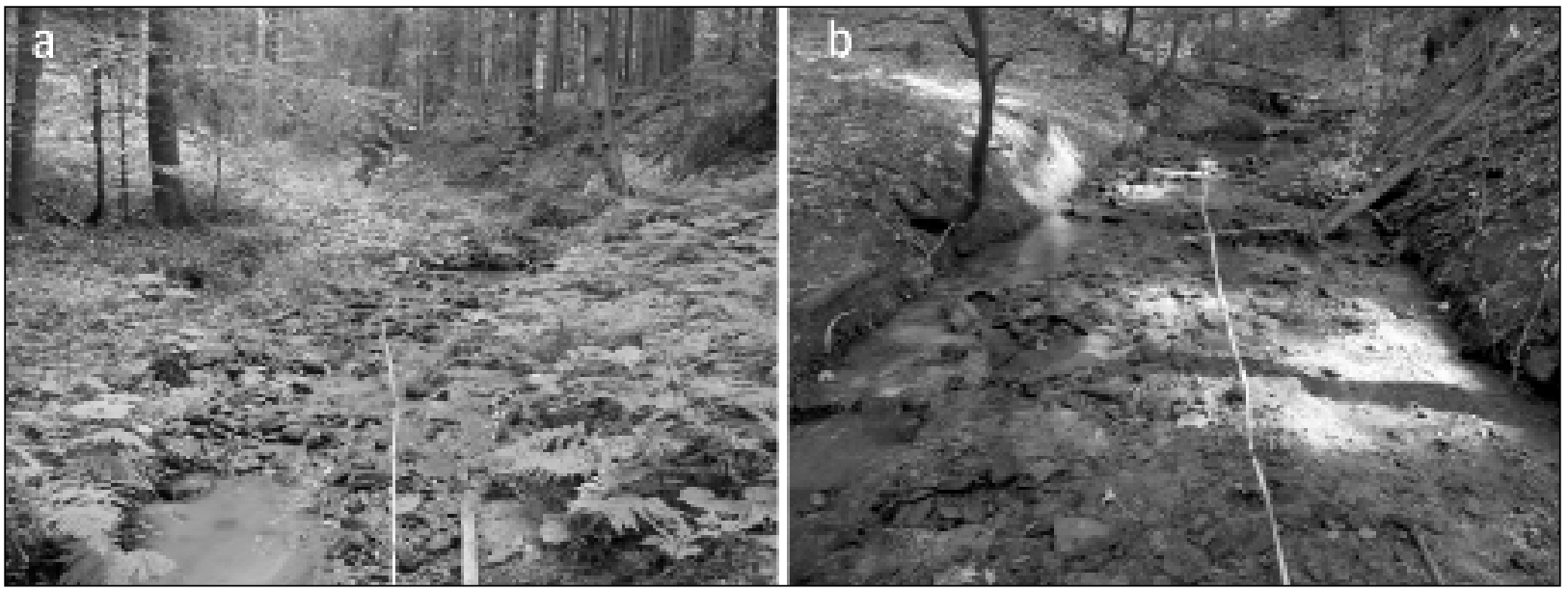

Obr. 3: a - Neckovitý tvar údolí s nižší úrovní zaplavované nivy při extrémních povodních Pulčínského potoka; b - široké koryto vodního toku Pulčínského potoka.

Fig. 3: a - Trapezoid shape and floodplain of the Pulčínský potok stream; b - wide channel of the Pulčínský potok stream. 
terizují zákruty o poloměru cca $20 \mathrm{~m}$. Délka studovaného úseku byla $860 \mathrm{~m}$. Celková plocha povodí Pulčínského potoka je $7,39 \mathrm{~km}^{2}$.

\section{Metodická východiska}

Terénní práce probíhaly v letním období roku 2012. Byly vybrány dva vodní toky v Hostýnsko-vsetínské hornatině a Javornících. Předpokladem byl výskyt pískovcových hornin budujících tato dvě povodí pro vzájemné porovnání výsledků. Měření a terénní průzkum ve studovaných úsecích probíhal vždy ve směru po proudu. Metodika je založena na sběru vždy 5 největších klastů (především balvanů) $\mathrm{v}$ přičném profilu koryta vodního toku vždy $\mathrm{v}$ intervalu po $10 \pm 1 \mathrm{~m}$ v podélném profilu proudnice toku (dle metodiky Galia - Škarpich 2013). Tyto hodnocené klasty byly ve všech př́ípadech tvořeny pískovci. Zaměřeny byly vždy tři základní osy klastu $a, b$ a $c$ s přesností na půl centimetru (dle metodiky Bunte - Abt 2001). Následně byly vypočteny charakteristiky indexu velikosti klastu (nominal diameter), který vychází ze vztahu: $D_{n 5}=\left(a^{*} b^{*} c\right)^{1 / 3}$, kde $a, b, c$ jsou jednotlivé osy těchto klastů (Bunte - Abt 2001). Obecně lze konstatovat, že poproudové trendy ve velikosti 5 největších klastů odráží charakter koluviálních a fluviálních procesů ve svahovo-korytovém subsystému fluviálního (dis)kontinua. Lze předpokládat, že při výskytu větších klastů (valounů) v korytě vodního toku v horních úsecích povodí vysokogradientových toků není schopna proudící voda (při dané transportní kapacitě koryta) rozpohybovat tyto klasty. Hypoteticky se tedy jedná o klasty, které sem byly dopraveny především gravitační činností (resp. koluviálními procesy) z přilehlých svahů a jsou zde dočasně uloženy. Při následném opracovávání fluviálními procesy (rozbitím okolními pohybujícími se klasty při vyšších průtocích) mohou být po dosažení určité velikosti klastu rozpohybovány proudící vodou př̀ povodňových průtocích. V průběhu terénních prací byly zaměřeny také základní parametry koryta: šířka koryta a lokální sklon vždy v intervalu $50 \pm 1 \mathrm{~m}$.

\section{Výsledky a diskuze}

Vývoj trendů průměrných hodnot indexu $D_{n 5}$ vykazuje $\mathrm{v}$ podélném průběhu obou vodních toků značně rozkolísaný průběh. Především v horní části studovaného úseku Kobylské jsou patrné zvýšené hodnoty tohoto indexu $D_{n 5}$. Obecně lze konstatovat, že v korytě Kobylské se $\mathrm{v}$ horní části studovaného úseku vyskytují mnohem (místy až dvojnásobně) větší klasty oproti dolnímu úseku a dochází zde $\mathrm{k}$ výskytu větších valounů.
Tento stav je patrně způsoben př́sunem hrubého klastického materiálu z přilehlých svahů, jehož velikost překračuje lokální transportní kapacitu toku. Úsek koryta by se dal charakterizovat jako značně omezený ( $\mathrm{z}$ angl. confined) nebo částečně omezený ( $\mathrm{z}$ angl. partially confined) sensu Fryirs et al. (2007), kdy jsou svahy v kontaktu s vodním tokem a materiál je transportován přímo do koryta. Celá studovaná oblast je také budována mocnějšími pískovcovými lavicemi (mocnost od 10 do $40 \mathrm{~cm}$ ), které se prrímo podílejí na zvýšené velikosti sledovaných klastů. Tyto mocnější lavice pískovců lze vypozorovat v korytě vodního toku, kde tvoří skalní stupně a kaskády (viz obr. 2a, b). Proudící voda právě klasty $\mathrm{z}$ těchto mocnějších pískovcových lavic není schopna při dané transportní kapacitě rozpohybovat a ty jsou tak dočasně uloženy v korytě. Fakt zvýšené dodávky přímo z přilehlých svahů podporuje také výskyt mohutných břehových nátrží, ze kterých je zcela jistě vodní tok zásobován hrubým sedimentárním materiálem při vyšších vodních stavech. Částečně problematický se může jevit zvýšený lokální sklon v horním úseku Kobylské (viz obr. 4, cca 90 a $120 \mathrm{~m}$ od počátku studovaného úseku v podélném průběhu toku). Zvýšení těchto hodnot lokálního sklonu by mohlo být spojováno v tomto úseku se zvýšením indexu $D_{n 5}$. Na základě dosud realizovaných studií (sensu Kondolf 1997; Škarpich et al. 2010, 2012) lze konstatovat, že zvýšení lokálního sklonu má vliv především na úsek vždy pod daným stupněm (v literatuře jsou tyto formy v korytě někdy též popisovány jako diskonektivity) ve smyslu hrubnutí akumulovaných sedimentů zvýšením energie proudící vody a odplavením jemnějších frakcí sedimentů. $\mathrm{V}$ úsecích nad těmito stupni by pak snížením energie proudící vody vlivem sníženého lokálního sklonu mělo docházet také $\mathrm{k}$ výskytu jemnějších frakcí akumulovaných v korytě. Hrubší frakce také mnohdy bý-

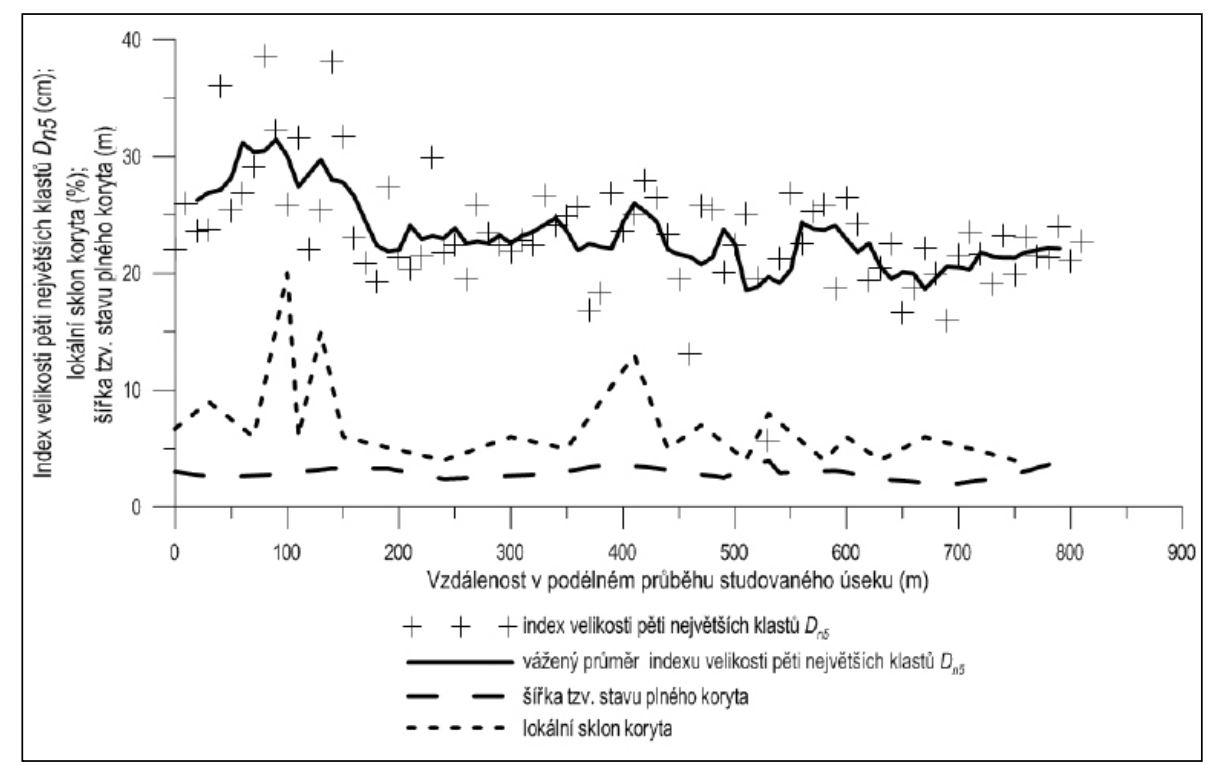

Obr. 4: Index velikosti pěti největších klastů $D_{n 5}$, lokální sklon koryta a šírka tzv. stavu plného koryta v podélném průběhu vodního toku Kobylská, vzdálenost $\mathrm{v}$ podélném průběhu je uváděna směrem po proudu toku.

Fig. 4: Nominal diameter of the five largest boulders $\left(D_{n 5}\right)$, local channel gradient and bankfull width in the longitudinal profile of the Kobylská stream, distance in the longitudinal profile is measured downstream. 


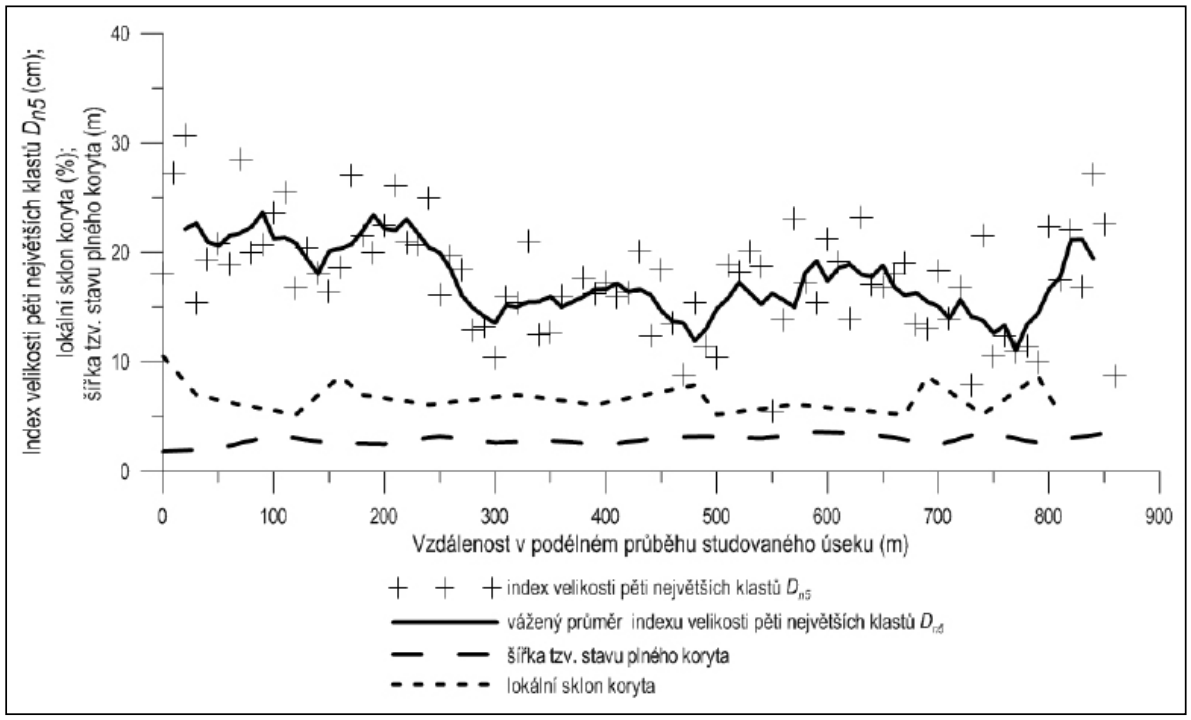

Obr. 5: Index velikosti pěti největších klastů $\left(D_{n 5}\right)$, lokální sklon koryta a šířka tzv. stavu plného koryta v podélném průběhu vodního toku Pulčínský potok, vzdálenost v podélném průběhu je uváděna směrem po proudu toku.

Fig. 5: Nominal diameter of the five largest boulders $\left(D_{n 5}\right)$, local channel gradient and bankfull width in the longitudinal profile of the Pulčínský potok stream, distance in the longitudinal profile is measured downstream.

vají překryty těmito akumulovanými jemnějšími frakcemi a ty nemusejí být v korytě identifikovatelné. U vodního toku Kobylské jsou tyto obecně platné zákonitosti patrné mírným snížením indexu $D_{n 5}$ nad těmito stupni (diskonektivitami) (viz obr. 4).

Analýza indexu $D_{n 5} \mathrm{v}$ podélném průběhu Pulčínského potoka nevykazuje významnější odchylky např. ve zvýšení hodnot (obr. 5). Tyto hodnoty mají sice rozkolísaný průběh, ale nelze zde identifikovat, např. jako u vodního toku Kobylská, zvýšenou dodávku sedimentů z přilehlých svahů gravitačními procesy do koryta $\mathrm{v}$ podobě zvýšení indexu $D_{n 5}$. Oblast povodí je podobně jako u vodního toku Kobylská budována mocnějšími vrstvami pískovcových hornin (a také slepenci). Ovšem v podélném průběhu toku se při této analýze dodávka větších valounů do koryta nikde neprojevuje zvýšenými hodnotami $D_{n 5}$. Důvodem je charakter údolního dna, které je charakterizováno neckovitým tvarem $\mathrm{v}$ příčném profilu s vyskytujícími se menšími říčními terasami. Vodní tok lze zde definovat jako částečně omezený (z angl. partially confined) nebo neomezený ( $\mathrm{z}$ angl. unconfined) sensu Fryirs et al. (2007). Svahy tak neprriléhají přímo ke korytu vodního toku a dodávka sedimentů je omezena tzv. laterálními diskonektivitami v po- době již zmíněných lokálně vyskytujících se říčních teras sensu Fryirs et al. (2007). Tento trend se projevuje také $\mathrm{v}$ nízkém počtu a velikosti sledovaných břehových nátrží. Nicméně v dolní části sledovaného profilu (cca $780-850 \mathrm{~m}$ od počátku) lze ukázat na poproudový nárůst $D_{n 5}$, který může být odrazem zvýšené transportní kapacity se zvýšenou rychlostí proudění vody. V samotném korytě jsou tyto procesy pozorované zrychlenou erozí a postupným zahlubováním toku v tomto úseku.

\section{Závěry}

Metoda sběru, měření a mapování nejhrubší frakce korytových sedimentů může být nástrojem $\mathrm{v}$ identifikaci zdrojových oblastí sedimentů pro vodní toky v systému svah-koryto. Je však nutné brát vždy v potaz lokální charakteristiky horninového složení zdrojového materiálu, především pak zrnitost, petrografické složení a mocnost vrstev $\mathrm{v}$ př́ípadě sedimentárních hornin. U oblastí budovaných jílovcovými horninami je především jejich vyšší erodibilita a rozpadavost velkou překážkou v jednoznačné identifikaci zdrojů materiálu výše popisovanou metodou. Takto vzniklé jemnější zrnitostní frakce jsou okamžitě fluviálně transportovány a nelze tak odraz konkrétních materiálových zdrojů $\mathrm{v}$ přilehlých korytových sedimentech zhodnotit. Oproti tomu u oblastí budovaných pískovcovými horninami dodávajícími do koryta poměrně hrubší klastický materiál, lze předpokládat, že právě velké klasty transportované gravitačními procesy do koryta nemohou být fluviálními procesy rozpohybovány a jsou tak v korytových úsecích přiléhajících ke svahům s výskytem jejich zdrojů dlouhodobě akumulovány.

\section{Poděkování}

Př́spěvek vznikl za podpory interního grantu Ostravské univerzity SGS4/PřF/2012. Autoři děkují Mgr. Danielu Nývltovi, Ph.D. za cenné připomínky v recenzním řizení. 


\section{Literatura}

Bunte, K. - Abt, S. R. (2001): Sampling surface and subsurface particle-size distributions in wadable gravel-and cobble-bed streams for analyses in sediment transport, hydraulics, and streambed monitoring. - 1-428, Gen. Tech. Rep. RMRS-GTR-74. Fort Collins, CO: U.S. Department of Agriculture, Forest Service, Rocky Mountain Research Station.

Fryirs, K. A. - Brierley, G. J. - Preston, N. J. - Spencer, J. (2007): Catchment-scale (dis)connectivity in sediment flux in the upper Hunter catchment. - Geomorphology, 84, 297-316.

Galia, T. - Škarpich, V. (2013): Coarse bed sediments in a headwater channel as indicators of fluvial processes and slope-channel coupling: a case study from the Carpathian Mountains (Czech Republic). - Moravian geographical report, 21, 2-11.

Golden, A. R. - Springer, G.S. (2006): Hydraulic geometry, median grain size, and stream power in small mountain streams. Geomorphology 78, 64-76.

Kondolf, G. M. (1997): Hungry water effects of dams and gravel mining on river channels. - Environmental management, 21, 533-551.

Montgomery, D. R. - Buffington, J. M. (1997): Channel reach morphology in mountain drainage basins. - Geological Society of America Bulletin, 109, 596-611.

Owczarek, P. (2008): Hillslope deposits in gravel-bed rivers and their effects on the evolution of alluvial channel forms: A case study from the Sudetes and Carpathian Mountains. - Geomorphology, 98, 111-125.

Pesl, V. (1991): Geologická mapa ČR 1 : 50000 - list 25-23 Rožnov pod Radhoštěm. - Český geologický ústav.

Krejčí, O. (1991): Geologická mapa ČR 1:50 000 - list 25-41 Vsetín. - Český geologický ústav.

Recking, A. - Leduc, P. - Liébault, F. - Church, M. (2012): A field investigation of the influence of sediment supply on step-pool morphology and stability. - Geomorphology, 139-140, 53-66.

Škarpich, V. - Galia, T. - Hradecký, J. - Peč, J. (2010): Identifikace (dis)konektivit vodních toků za využití makrogranulometrické analýzy korytových sedimentů (Moravskoslezské Beskydy). - Geologické výzkumy na Moravě a ve Slezsku, 17, 199-204.

Škarpich, V. - Galia, T. - Hradecký, J. (2012): Podmínky transportu a akumulace sedimentů v člověkem ovlivněných korytech beskydských toků: př́kladová studie soutoku řeky Morávky a Mohelnice. - Geologické výzkumy na Moravě a ve Slezsku, 19, 53-58.

Theler, D. - Reynard, E. - Lambiel, C. - Bardou, E. (2010): The contribution of geomorphological mapping to sediment transfer evaluation in small alpine catchments. - Geomorphology, 124, 113-123. 